\title{
Pathophysiology of Upper Airway Collapse
}

\author{
Ki Ju Cho ${ }^{1}$ and Sang-Wook Kim ${ }^{1,2,3}$ (D) \\ ${ }^{1}$ Department of Otorhinolaryngology, Gyeongsang National University Hospital, Jinju; and \\ ${ }^{2}$ Department of Otorhinolaryngology, Gyeongsang National University College of Medicine, Jinju; and \\ ${ }^{3}$ Institute of Health Sciences, Gyeongsang National University, Jinju, Korea
}

\section{상기도 폐쇄 병태생리}

조기주 ${ }^{1} \cdot$ 김상욱 ${ }^{1,23}$

경상대학교병원 이비인후과, ${ }^{1}$ 경상대학교 의과대학 이비인후과학교실, ${ }^{2}$ 경상대학교 건강과학연구원 ${ }^{3}$

Received November 4, 2020

Revised December 9, 2020

Accepted December 14, 2020

Address for correspondence

Sang-Wook Kim, MD, PhD

Department of Otorhinolaryngology,

Gyeongsang National University

Hospital, 79 Gangnam-ro,

Jinju 52727, Korea

Tel $+82-55-750-8177$

Fax $+82-55-759-0613$

E-mail basilent@gnu.ac.kr
Previous pathophysiologic studies have revealed that the upper airway dimension reaches a minimal value at the end of expiration, and pharyngeal negative pressure is not an essential prerequisite for upper airway collapse. Furthermore, pharyngeal collapse occurs in spite of increased activity of upper airway dilator muscles in patients with obstructive sleep apnea (OSA) compared with normal subjects. Pharyngeal sensory threshold is elevated in patients with OSA, which contributes to inadequate activity of upper airway dilator muscles. Pharyngeal narrowing results in several types of airflow limitation, of whom the mechanisms are mainly explained using Starling resistor model and negative effort dependence. Several studies have been conducted over the past years to validate polysomnographic surrogate markers which indicate specific pathophysiologic phenotypes, and such attempts may be able to lead us to personalized treatment for OSA. Korean J Otorhinolaryngol-Head Neck Surg 2020;63(12):551-7

\section{서 론}

폐쇄성 수면무호흡(obstructive sleep apnea, OSA)은 흔히 수면 중에 연구개와 혀 등의 연부 조직을 구성하는 근육들이 이완되면서 기도를 막아 일시적으로 호흡이 단절되는 질환이 며, 흡기 시 상기도 내에 발생하는 음압이 이러한 상기도 폐쇄 에 주된 역할을 하는 것으로 알려져 있다. 이러한 배경에서 OSA 환자의 상기도 폐쇄 부위를 진단하는 검사법으로 상기 도 내 음압을 유도하는 Muiller maneuver가 이용되어 온 것도 합리적인 선택이었던 것으로 생각된다. ${ }^{1)}$ 하지만, 아직 OSA 환자에서 발생하는 상기도 폐쇄 기전에 대해서는 명확히 밝 혀지지 않았다. 지난 2014년에 OSA의 새로운 치료법으로 Food and Drug Administration 승인을 받은 설하신경 자극

This is an Open Access article distributed under the terms of the Creative Commons Attribution Non-Commercial License (https://creativecommons.org/licenses/by-nc/4.0) which permits unrestricted non-commercial use, distribution, and reproduction in any medium, provided the original work is properly cited. 치료(hypoglossal nerve stimulation, HGNS)도 해부학적 접 근에 기반해서 고안이 되었던 기존의 수술법들과 달리 병태 생리 연구에서 출발하였으며, 굴곡형 내시경으로 상기도를 관찰하면서 상기도 확장근의 근전도를 측정한 결과 무호흡 이 있을 때 근육 활성도가 저하되는 결과를 확인한 데서 시 작되었다. ${ }^{2)}$ 설하신경의 외측 분지는 혀를 뒤로 움직이는 경상 설근(styloglossus), 설골설근(hyoglossus) 등을 지배하는 반면 내측 분지는 혀를 앞으로 내미는 이설근(genioglossus) 등을 지배하므로 이에 근거하여 Medtronic에서 설하신경의 내측 분지만을 전기 자극하는 소매(cuff) 형태의 전극을 개발하여 개 모델에서 그 효과를 확인하였으며, ${ }^{3)}$ 이후 일련의 임상시 험들을 거쳐 OSA 환자에서 치료 효과가 검증되었고, ${ }^{4,5}$ 이후 미국과 유럽에서 $\mathrm{OSA}$ 의 새로운 치료법으로서 승인을 받고 활발히 시행되고 있다. ${ }^{6} \mathrm{HGNS}$ 가 OSA의 새로운 치료법으 로 등장하기는 했지만 이를 포함한 여러 수술법과 지속기도 양압술(continuous positive airway pressure, CPAP) 혹은 
구강 내 장치 등 OSA의 주된 현행 치료법들 중 어떤 것도 치 료효과, 안전성 및 순응도라는 측면을 모두 만족시키는 이상 적인 치료법은 없다. 새로운 치료법의 개발은 질환의 병태생 리에 대한 보다 깊은 이해에 기반한다는 점에서 OSA 환자에 서 발생하는 상기도 폐쇄의 병태생리에 대한 기존의 연구 결 과들을 정리해 보고자 한다.

\section{호흡 주기에 따른 상기도 단면적의 변화}

\section{상기도 폐쇄가 일어나는 시점}

상기도 음압이 상기도 폐쇄를 일으키는 주된 요인이라면 상기도 면적이 가장 좁아지는 시점은 흡기 중 한 시점이 될 것이다. 하지만, OSA 환자에서 CT를 이용해서 호흡 주기에 따른 연구개 뒤 공간(retropalatal area)의 상기도 단면적 변 화를 조사한 연구에 따르면 호기 중반에 상기도 단면적이 최 대로 증가했다가 서서히 감소하면서 호기 말에 단면적이 가장 좁아지고 흡기 시에는 이보다 단면적이 약간 넓어지면서 비교 적 흡기 내내 일정한 단면적이 유지된다. 물론 상기도 단면 적이 완전 폐쇄되는 무호흡 시에는 호기 말뿐만 아니라 흡기 내내 상기도가 폐쇄된 채로 유지가 되겠지만 상기도 내강이 완전 폐쇄가 되지 않는 경우에는 대부분 흡기 중이 아닌 호기 말에 가장 좁은 단면적을 보인다는 것이다. 또한, 정상 피험 자와 OSA 환자 모두 각성 시에 비해 수면 중 흡기-호기에 따른 상기도 단면적의 변화폭이 커졌으며, OSA 환자에서는 각성 시나 수면 중 모두 정상 피험자에 비해 상기도 단면적 의 변화폭이 컸다. ${ }^{8}$ 이러한 현상이 나타나는 이유는 호기 중 에는 상기도 확장근이 비활성화되는데 호기가 끝나는 시점 에는 호기량마저 줄어들어 상기도 내 압력이 떨어지는 것에 기인하며, 흡기 시에는 상기도 내에 음압이 형성됨에도 불구 하고 상기도 확장근이 활성화되어 상기도 음압에 대항하여 상기도 폐쇄를 막아주기 때문이다. 이로 인해, 상기도 확장 근이 비활성화되며 호기 압력이 최저치에 도달하는 호기 말 이 상기도 폐쇄에 가장 취약한 시점이 되는 것이다. ${ }^{9}$

\section{상기도 폐쇄와 상기도 음압과의 관계}

상기도 폐쇄압(closing pressure)에 대한 기존 연구 결과를 보면 정상 피험자에서는 상기도 폐쇄를 유발하기 위해서 상 기도 음압이 반드시 필요하다. 하지만, OSA 환자에서는 상기 도 압력이 대기압과 같거나 더 큰 양압 상태에서도 상기도 폐 쇄가 일어나며, 특히 oxygen desaturation index가 높은, 즉 중증도가 높은 OSA 환자에서는 이러한 경향이 더욱 두드러 진다. ${ }^{10)}$ 즉, 상기도 음압은 상기도 폐쇄의 필요조건이 아니다. 이러한 사실은 중추성 수면무호흡(central sleep apnea, CSA)
환자를 대상으로 한 연구에서도 확인되었다. CSA 환자를 대 상으로 굴곡형 내시경을 이용하여 상기도 단면적 변화를 관 찰한 결과 일부 환자에서 무호흡 시 상기도 폐쇄가 일어났다. 이렇게 상기도 음압이 유발되지 않는 중추성 무호흡에서도 상기도 폐쇄는 일어날 수 있다. ${ }^{11}$

\section{상기도 폐쇄와 해부학적 구조와의 관계}

$\mathrm{MRI}$ 등 영상 검사에 기반한 기존 연구 결과들을 보면 OSA 환자는 정상 피험자에 비해 평균적으로 두개안면골격(craniofacial structure)의 크기가 작고, 구인두를 이루는 연조직 들의 부피는 커서 결과적으로 상기도 단면적이 좁아진다고 알려져 있다. ${ }^{12)}$ 또한, 인종간 혹은 남녀 간의 해부학적 골격의 차이가 OSA 유병률의 차이와 연관된다는 연구 결과들(가령, 폐쇄가 일어날 수 있는 상기도의 길이가 여성에 비해 남성에 서 유의하게 긺)을 보면 해부학적 요인이 상기도 폐쇄의 위험 인자임은 분명해 보인다. ${ }^{13,14)}$ 또한, 골격이나 연조직 구조의 차 이뿐 아니라 자세나 입 벌림도 상기도 단면적에 영향을 미친 다. 즉, 목을 뒤로 젖히면 기도 단면적이 넓어지고 앞으로 숙 이면 기도 단면적이 좁아지고, 입을 벌리게 되면 하악골이 아 래, 뒤쪽으로 회전을 하면서 설골(hyoid bone) 및 설골에 부 착하는 혀근육도 뒤로 밀리면서 상기도 면적이 좁아지게 된 다. ${ }^{15)}$ 따라서, 목이 앞으로 꺾일 정도의 높은 베개는 무호흡을 악화시킬 수 있으며, 코막힘 등의 이유로 잠을 잘 때 입이 벌 어지게 되면 무호흡이 심해질 수 있다. 또한, 폐 용적도 상기 도 단면적에 영향을 미친다. 폐 용적이 커질수록 흡기 시 기 관(trachea)을 아래쪽으로 당기면서 상기도의 조직압(tissue pressure)을 낮춤으로써 상기도 단면적을 늘리기 때문이다. ${ }^{16)}$

\section{상기도 폐쇄와 상기도 조직 특성과의 관계}

해부학적 특징이 상기도 폐쇄의 위험인자라고 하더라도 그 자체로는 수면 중 상기도 단면적이 점점 줄어들다가 폐쇄가 되는 기전을 설명해 주지는 못한다. 연조직으로 이루어져 있 어 내강의 압력 변화에 따라 폐쇄될 수 있는 상기도의 물리 학적 특성은 소위 tube law라는 법칙에 의해 설명이 된다. ${ }^{17}$ 즉, 상기도 벽에 작용하는 경벽압(transmural pressure, $\mathrm{P}_{\mathrm{tm}}$ ) 은 상기도의 내강 압력(luminal pressure, $\mathrm{P}_{\mathrm{L}}$ )과 상기도 주변 조직의 조직압의 차이에 의해 결정이 되며 이러한 경벽압이 증가할수록 상기도의 단면적은 정점을 향해 곡선 형태를 그 리며 증가하는 모습을 보인다(Fig. 1). 이는 상기도 단면적이 커질수록 경벽압 변화에 따른 단면적 변화는 적어지고(low compliance), 단면적이 작을수록 같은 경벽압 변화에 의해 단면적이 더 많이 좁아지는 양상(high compliance)을 보인다 는 것을 의미한다. OSA 환자는 정상 피험자에 비해 상기도 

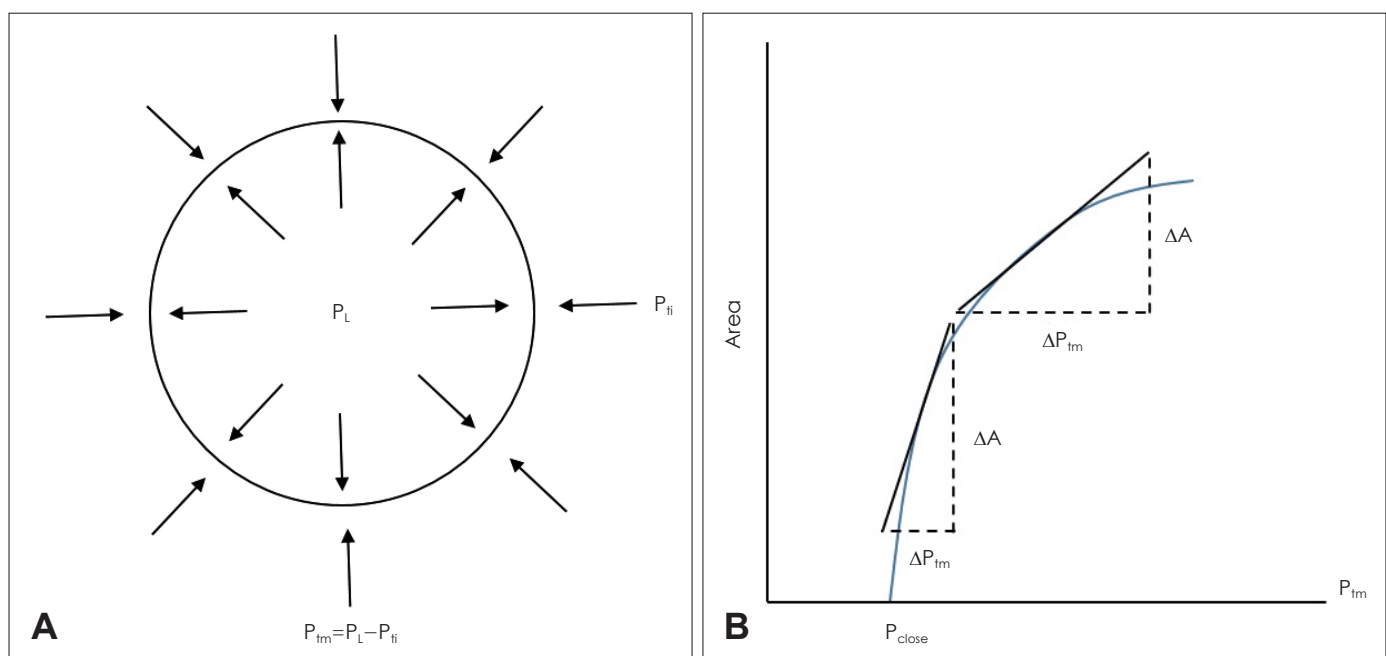

Fig. 1. The concept of a tube law of the pharynx $(A)$ and the $P_{t m}$-area curve in accordance with a tube law (B). Area means cross-sectional area of the pharynx. $P_{L}$ : luminal pressure, $P_{t i}$ : tissue pressure, $P_{t m}$ : transmural pressure, $P_{\text {close }}$ : closing pressure.

단면적 자체가 작은 경향이 있으므로 tube law에 의하면 작 은 경벽압의 변화에 의해서도 쉽게 상기도 폐쇄가 일어날 수 있다. 물론 이는 상기도가 수동적인 원통 구조라는 가정하에 서의 설명이고, 실제로는 상기도가 좁아지면 상기도 확장근이 활성화되면서 조직압이 낮아지고 경벽압이 높아지는 변화가 일어나므로 tube law에 의한 변화가 실제의 OSA 환자에서 그대로 적용이 될 수는 없지만, 뒤에서 설명할 Starling resistor model의 기본 전제가 된다는 점에서 이해할 필요가 있다.

\section{상기도 폐쇄와 상기도 확장근 활성도 간의 관계}

상기도 확장근들은 체내 $\mathrm{CO}_{2}$ 농도가 높아지거나 $\mathrm{O}_{2}$ 농도 가 낮아지면 활성화가 되는데 다른 포유류에서는 설골이 주 변의 연골이나 뼈와 직접 연결되어 있는 것과 달리, 사람에서 는 설골이 주변 근육들로만 지지되는 구조(floating structure)를 하고 있어 상기도 확장근들이 동시에 자극이 되면 설 골은 앞쪽, 아래쪽 방향으로 이동하면서 상기도가 넓어지게 된다." 또한, 상기도 확장근들의 활성도는 각성 시에 비해 수 면 중에 감소하게 되고 상기도의 단면적도 각성 시에 비해 non-rapid eye movement(NREM) 수면 단계에서, NREM 수면 단계에 비해서 rapid eye movement(REM) 수면 단계 에서 더 감소하는 경향을 보인다. 그리고, REM 수면 단계 중 에서도 빠른 안구 운동이 나타나지 않는 tonic REM 단계에 비해 빠른 안구 운동이 주기적으로 반복되는 phasic REM 수면 단계에서 상기도 단면적이 더욱 줄어들며 이러한 변화 는 상기도 근육의 활성도 변화와 연관되는 것으로 알려져 있 다. ${ }^{18)}$ 대표적 상기도 확장근인 이설근은 정상적으로 수면 중 에 활성도가 감소하며 이는 상기도 저항의 증가로 이어진다. $\mathrm{OSA}$ 환자에서는 각성 시에도 상기도 저항이 정상인에 비해
높게 측정되며, 수면 중에는 그 차이가 더욱 두드러지는 것으 로 알려져 있다. ${ }^{9}$

앞서 언급한 tube law에 따르면 이론적으로 상기도 단면 적의 감소는 상기도 순응도(compliance)의 증가로 이어진다. 하지만, 실제로는 이설근과 같은 상기도 확장근의 활성도가 수면 단계가 깊어짐에 따라 감소하고 이에 따라 상기도 단면 적이 줄어듦에도 불구하고 상기도 순응도(압력 변화에 따른 단면적의 변화)는 예상과 달리 증가하지 않으며, 특히 근육 활 성도 저하가 가장 현저히 나타나는 phasic REM 수면 단계 에서도 상기도 순응도는 다른 수면 단계와 비교해서 별 차이 를 보이지 않는다. ${ }^{19,20)}$ 또한, OSA 환자에서는 정상 피험자에 비해 상기도 순응도가 증가되어 있음에도 불구하고 이설근의 근전도상 활성도는 오히려 정상 피험자에 비해 높게 유지된 다. ${ }^{21)}$ 즉, $\mathrm{OSA}$ 환자에서 정상 피험자에 비해 증가된 상기도 순응도는 상기도 확장근의 활성도가 떨어졌기 때문이 아니라 상기도 확장근의 활성도가 정상 피험자에 비해 높게 유지됨 에도 불구하고 나타나는 현상이다. 이는 상기도 폐쇄가 어떤 기전에 의해 발생하는지는 아직 정확히 모르지만 적어도 단 순히 상기도 확장근의 활성도가 떨어짐으로 인해 생기는 것 은 아니라는 점을 보여준다.

\section{상기도 확장근의 기능부전}

상기도 확장근은 이설근처럼 흡기시에 활성화되는 위상근 (phasic muscle)과 구개범장근(tensor veli palatini muscle)과 같이 호흡 주기와 관계없이 수축을 하는 긴장근(tonic muscle)으로 나뉘게 되며 횡격막을 비롯한 흥곽펌프근육(thoracic pump muscle)보다 약 $200 \mathrm{~ms}$ 정도 먼저 활성화가 되어 흡기 시 상기도 내강이 안정적으로 유지되도록 하는 것으로 알 
려져 있다. ${ }^{22)}$ 이러한 상기도 확장근은 상기도 개방에 있어 매 우 중요한 역할을 하는데 이설근의 힘을 $\mathrm{CPAP}$ 치료 전후에 측정한 한 연구에 따르면 $\mathrm{CPAP}$ 치료 후 이설근의 기능이 향 상될 수 있다. ${ }^{23)}$ 이 연구에서는 OSA 환자와 정상 피험자를 대상으로 턱 밑 피부에 $3 \mathrm{~cm}$ 정도의 횡절개를 넣고 이설근에 서 $4 \times 4 \mathrm{~mm}$ 크기의 조직을 얻어서 피로도 분석을 하였다. 근 육의 힘은 시간이 흐름에 따라 서서히 감소하는 피로 현상을 보이는데 정상 피험자에 비해 OSA 환자에서 채취한 이설근 에서는 피로 현상이 급격히 진행되었으며, CPAP 치료를 시행 받은 OSA 환자에서는 정상 피험자와 유사한 근육의 피로도 를 보여주었다. 또한, 근육 조직 염색을 통해 근섬유의 종류를 분석했을 때 OSA 환자의 이설근은 정상 피험자에 비해 쉽게 피로에 빠지는 type II 근섬유가 유의하게 증가한 모습을 볼 수 있었으며, CPAP 치료를 받은 OSA 환자에서는 정상 피험 자와 비슷하게 type I 근섬유가 더 많은 것을 확인할 수 있었 다. 즉, $\mathrm{OSA}$ 를 치료하지 않고 방치를 하면 상기도 확장근들의 구성 중 쉽게 피로에 빠지는 type II 근섬유 비중이 높아져서 $\mathrm{OSA}$ 를 더욱 악화시키게 되며, 이러한 근섬유의 변화는 CPAP 치료에 의해 회복이 될 수 있는 가역적인 인자임을 시사한다.

상기도 확장근의 활성도는 상기도 점막의 감각 변화에 의 해서도 영향을 받는다. 한 연구에 따르면 OSA 환자의 상기도 점막의 진동 감각(vibration sensation) 역치가 CPAP 치료를 받은 환자들에서는 치료를 받지 않은 환자들에 비해 유의하 게 낮아진다. ${ }^{24)}$ 몇몇 후속 연구들에서도 비슷한 결과를 보고 하였으며, 이러한 상기도 감각 기능 저하는 중증의 OSA 환자 에서 더 현저하게 나타나는 경향을 보였다. ${ }^{25,26)}$ 이렇게 OSA 환자에서는 반복되는 코골이 진동과 상기도 음압에 의한 연 조직들의 점막 손상이 발생하고 이에 따른 점막 감각 손상은 상기도 확장근이 상기도가 좁아지는 변화에 대응하여 활성 화되는 반응을 저해하여 상기도 폐쇄를 더욱 악화시키는 것 으로 이해되고 있다.

$\mathrm{OSA}$ 환자에서는 상기도 단면적의 감소를 감지하여 상기 도 확장근이 활성화되는 기능이 저하되어 있는데다 상기도 확장근 내에 쉽게 피로해지는 type II 근섬유의 비중이 높아 져서 근육 활성도가 정상 피험자에 비해 높아져 있음에도 불 구하고 상기도가 폐쇄되는 결과로 이어진다고 볼 수 있다.

\section{상기도 단면적 변화와 기류 변화 간의 관계}

\section{Starling resistor model}

유동적이지 않은 비강/비인두와 하인두를 각각 상류(upstream)와 하류(downstream)로 두고, 폐쇄가 일어날 수 있
는 구인두 상기도를 단일한 주변 조직압(peri-airway pressure)을 갖는 유동적인 원통이라고 가정하면 하류의 압력이 특정 역치 이하로 내려가는 경우 유동적 원통 내에 폐색 지 점(chock point)이 발생하게 되며, 이 지점의 기도 단면적은 앞서 언급했던 tube law에 의해 상류 내강의 압력(upstream pressure, $\mathrm{P}_{\mathrm{us}}$ ) 혹은 하류 내강의 압력(downstream pressure, $\left.\mathrm{P}_{\mathrm{ds}}\right)$ 과 무관하게 폐색 지점에서의 경벽압 $\left(\mathrm{P}_{\mathrm{tm}}\right)$ 에 의해서 결정 된다(Fig. 1A). 폐색 지점이 발생하면 하류의 압력이 더 낮아 져도 그러한 압력 변화가 폐색 지점에 의해 차단되어 상류에 영향을 주지 못하고 상류의 압력은 일정하게 유지되며, 따라 서 상류를 통해 흐르는 기류의 양도 하류의 압력 변화에 영 향을 받지 않고 일정하게 유지된다. 폐색 지점에서의 내강 압 력 $\left(\mathrm{P}_{\mathrm{L}}\right)$ 을 임계압(critical pressure, $\left.\mathrm{P}_{\text {crit }}\right)$ 이라고 칭하는데, 이 러한 원통에서 기류의 양(luminal airflow)은 상류와 하류의 압력 차이 $\left(\mathrm{P}_{\mathrm{us}}-\mathrm{P}_{\mathrm{ds}}\right)$ 가 아닌 상류와 폐색 지점의 압력 차이 $\left(\mathrm{P}_{\mathrm{us}}-\mathrm{P}_{\text {crit }}\right)$ 에 의해 결정된다(Fig. $\left.2 \mathrm{~A}\right)$. 이러한 모델을 Starling resistor model이라고 하며 원래 유동적 원통 구조인 요도나 혈관에서의 역학을 설명하던 개념인데 이후 OSA에서 상기 도 폐쇄를 설명하는 모델로 차용되었다. 실제 OSA 환자에서 비강 혹은 안면 마스크를 통해 일정 수준의 양압을 주면서 압력과 기류 간의 관계를 측정해보면 무호흡이 완전히 해소 되지 않고 저호흡이 지속되는 압력 범위에서 식도 내 음압이 지속적으로 낮아짐(호흡 노력의 증가)에도 불구하고 기류는 일정한 양을 유지하는 것을 확인할 수 있다. ${ }^{27)}$

한편, 폐쇄된 기도가 열릴 때의 $\mathrm{P}_{\text {crit }}$ 을 개방 임계압(opening $\mathrm{P}_{\text {crit }}$ ), 개방된 기도가 폐쇄될 때의 $\mathrm{P}_{\text {crit }}$ 을 폐쇄 임계압(closing $\left.\mathrm{P}_{\text {crit }}\right)$ 이라고 하는데 이 두 값은 대개 비슷하나 점막의 점도 등 에 의한 표면장력 정도에 따라 상기도 개방 시에 더 많은 압 력이 필요한, 즉 개방 임계압이 폐쇄 임계압보다 더 큰 경우도 있다. 또한, $\mathrm{P}_{\text {crit }}$ 값은 개인마다 두개안면골격 및 연조직의 해 부학적 구조 등에 의해 많은 차이가 있을 수 있으며, 한 개인 에서도 NREM과 REM 수면 단계에 따라 달라지게 되고 상 기도 확장근의 기능에 따라서도 변하게 되는데 이를 active $\mathrm{P}_{\text {crit }}$ 이라고 한다. ${ }^{27)}$

\section{Negative effort dependence}

실제 사람의 상기도는 Starling resistor model에서 가정하 는 단일한 주변 조직압을 받는 균일한 원통이 아니라 연구개 와 혀 등 분리된 구조물들로 둘러싸여 있으므로 Starling resistor model로 설명되지 않는 패턴을 자주 보인다. 흡기 시 보이는 다양한 기류 패턴을 분석한 연구에 따르면 남성 OSA 환자 일부에서 Starling resistor model에 부합하는 호흡 기류 패턴이 여성에 비해 상대적으로 흔하긴 하지만, 성별에 관계 


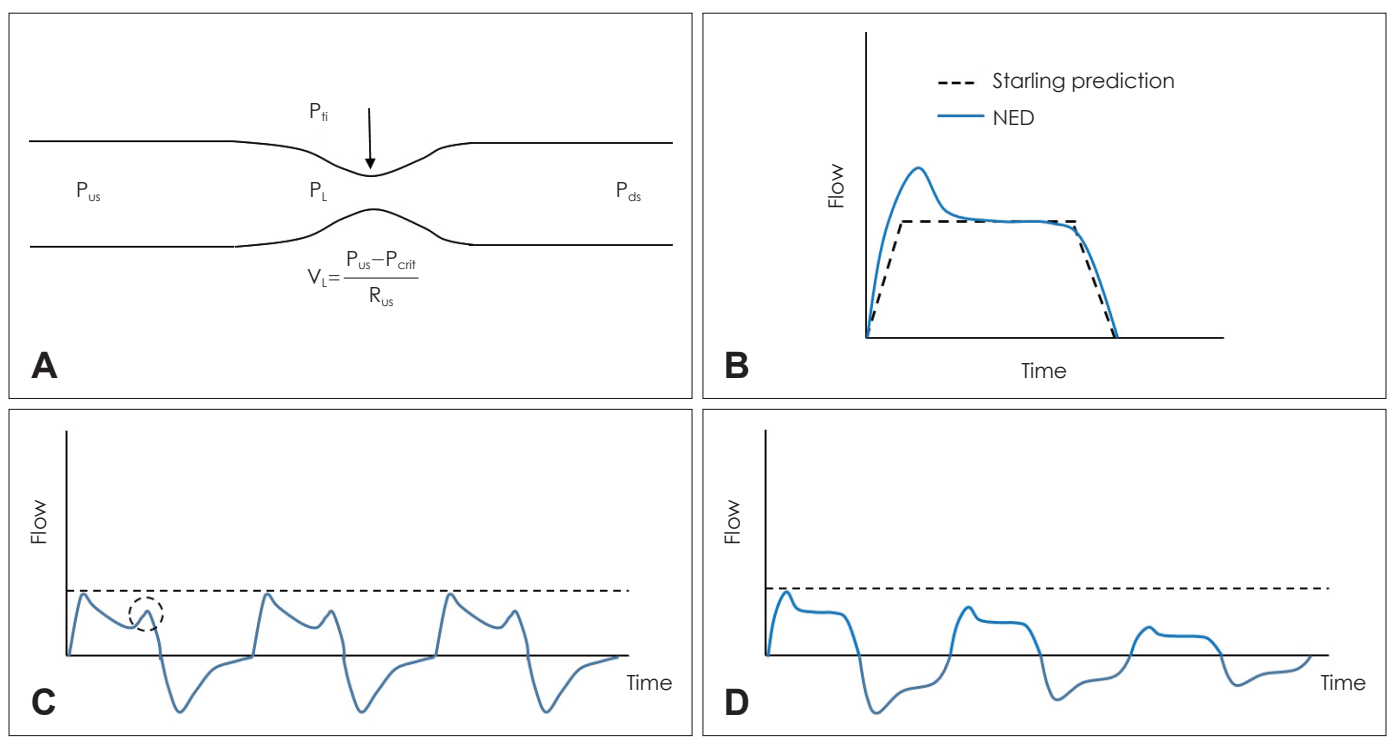

Fig. 2. The concept of Starling resistor model (A) and comparison of airflow limitation between Starling resistor model-based prediction and NED (B). In a specific type of NED, each successive breath reaches the same peak inspiratory flow (C), whereas the peak flow decreases with each successive breath in another type (D). $P_{t i t}$ : tissue pressure, $P_{u s}$ : upstream pressure, $P_{L}$ : luminal pressure, $P_{d s}$ : downstream pressure, $P_{\text {crit }}$ : critical pressure, $V_{L}$ : luminal airflow, $R_{\text {us }}$ : upstream resistance, NED: negative effort dependence.

없이 보다 많은 환자에서 흡기 초반에 봉우리를 형성한 뒤 급 격히 기류가 감소하는 패턴을 보이며, 이렇게 호흡 노력(effort)에 의해 호흡 기류가 감소하는(negative) 패턴을 가리켜 negative effort dependence(NED)라고 한다(Fig. 2B) ${ }^{28)} \mathrm{NED}$ 의 정확한 기전은 밝혀져 있지 않지만 혀와 같은 개별 구조물 이 덩어리(lump)로 움직이면서 원통 형태의 상기도 모델로는 설명되지 않는 움직임을 보이는 것으로 이해되고 있으며, 상 기도 점막에서 감지된 기류 변화가 상기도 확장근의 활성화를 유도하는 반사 회로가 정상 기능을 소실한 것이 주요 원인 중 하나로 추정되고 있다. NED는 두 가지 패턴으로 나눠볼 수 있는데 흡기 말에 호흡 기류가 일시적으로 다시 상승하면서 (terminal peak)를 보이면서 기저 호흡량이 Starling resistor model처럼 일정하게 유지된 채로 기류 제한(flow limitation)이 지속되는 경우가 있고(Fig. 2 C), terminal peak 없이 상기도내 음압이 점점 심해질수록 기저 호흡량이 감소하는 양상을 보이는 경우가 있다(Fig. 2D). ${ }^{29)}$

\section{병태생리 연구의 임상 적용: Bench to Bedside}

위에서 기술한 일련의 연구들을 통해 OSA 환자에서 발생 하는 상기도 폐쇄에 있어 해부학적 구조, 상기도 조직 특성 및 상기도 확장근 및 감각기능의 부전 등이 관여한다는 것이 밝 혀졌으며, Starling resistor model과 NED라는 개념을 바탕 으로 환자의 수면 중 나타나는 호흡 기류의 패턴을 보고 해당 환자에서 상기도가 어떠한 기전으로 폐쇄가 되는지를 추정
할 수 있게 되었다. 하지만, 여전히 상기도 폐쇄가 어떤 기전을 통해 일어나는지 명확히 밝히지 못한 한계도 분명히 있다.

한편, 병태생리 연구를 통해 지식들이 축적이 되면서 이를 진단과 치료에 적용하려는 시도가 자연스럽게 뒤따랐는데 대 표적으로 2013년에 OSA 환자의 표현형(phenotype)을 분류 하고 이를 바탕으로 환자별 맞춤형 치료, 즉 정밀의료의 구 현을 위한 시도가 있었다. ${ }^{30)}$ 이 연구에 따르면 OSA는 높은 $\mathrm{P}_{\text {crit, }}$ 낮은 상기도 확장근의 반응성(muscle responsiveness), 낮은 각성 역치(arousal threshold) 및 high loop gain이라는 개념으로 설명되는 호흡 조절의 불안정(ventilatory instability)의 4가지 특성이 혼재되어 있는 질환이며 $\mathrm{P}_{\text {crit }}$ 으로 대변되 는 해부학적 요인이 중요한 인자이긴 하지만, 나머지 비해부 학적인 요인 또한 존재하며 환자에 따라 다른 주된 요인을 파악해서 치료적 접근을 달리할 필요가 있다고 제안하였다. 가령, $\mathrm{P}_{\mathrm{crit}}$ 이 높으면 $\mathrm{CPAP}$ 나 상기도 확장 수술이 도움이 될 수 있으며, 각성 역치가 낮은 경우 eszopiclone과 같이 각성 역치를 높일 수 있는 약물 사용이 도움이 되고, high loop gain을 보이는 환자는 산소를 투여함으로써 호흡 조절이 보 다 안정적으로 이루어질 수 있게 할 수 있다는 것이다. 문제 는 이러한 OSA의 표현형을 일반적으로 시행하는 수면다원 검사(polysomnography, PSG) 결과로는 확인할 수가 없어서 실용적이지 않았다는 점인데 최근에는 여러 병태생리 연구 를 통해 도출된 이러한 표현형을 PSG 결과를 바탕으로 확인 할 수 있도록 대리 표지자(surrogate marker)를 찾는 연구도 이루어졌으며, 이미 $\mathrm{P}_{\text {crit, }}$ 상기도 확장근의 반응성 및 각성 역 치를 PSG 결과를 통해 상당 부분 확인할 수 있는 가능성이 
보고되었다. ${ }^{31-34)}$ 또한, 내시경 등으로 상기도의 해부학적 변 화를 직접 관찰하지 않고 $\mathrm{PSG}$ 의 호흡 기류 변화 만으로 상 기도 내에서 일어나는 해부학적 변화를 추정할 수 있다는 연 구 결과도 있다. 즉, 자연 수면 상태에서 굴곡형 내시경으로 상기도를 관찰해 보면 호기 중에 연구개가 비인강 쪽으로 뒤 집히면서 후인두벽에 붙어 폐쇄를 일으키는 연구개 탈출(palatal prolapse) 시에는 호흡 기류가 급격히 멈추면서 호기시 무호흡 양상을 보이는데 이렇게 PSG 검사 중 호흡 기류에서 호기시 급격히 나타나는 무호흡은 연구개 탈출을 시사한다고 볼 수 있다. ${ }^{35)}$ 만약 이러한 소견이 다수의 환자에서 일관되게 확인이 된다면 PSG 검사 중 연구개 탈출을 시사하는 호흡 기류를 보이는 경우 그러한 결과에 기반하여 연구개 수술을 계획하는 등의 선택이 가능해 질 수 있다.

\section{결 론}

OSA 환자에서 수면 중 상기도 폐쇄는 호기 말부터 발생하 며 상기도 음압이 없이도 상기도 폐쇄는 일어날 수 있다. 또 한, 상기도의 감각 기능 저하와 상기도 확장근 기능 부전으로 인해 상기도 확장근의 활성도가 높아져 있음에도 불구하고 상기도 폐쇄가 일어난다. 한편, 상기도 단면적 감소에 따른 기 류 변화는 개인마다 다양하게 나타날 수 있으며, 크게 Starling resistor model과 NED 기전으로 설명된다. 병태생리에 따른 OSA의 서로 다른 표현형을 PSG 검사에서 대리 표지자 를 이용해서 진단하려는 연구가 성공적으로 진행된다면, 향 후에 이를 기반으로 하여 환자별 표현형에 따른 맞춤형 치료 가 이루어질 가능성이 있다.

\section{Acknowledgments}

This work was supported by the Gyeongsang National University Fund for Professors on Sabbatical Leave, 2018.

\section{Author Contribution}

Conceptualization: Ki Ju Cho, Sang-Wook Kim. Data curation: Ki Ju Cho, Sang-Wook Kim. Formal analysis: Ki Ju Cho, SangWook Kim. Funding acquisition: Sang-Wook Kim. Investigation: Sang-Wook Kim. Methodology: Sang-Wook Kim. Project administration: Sang-Wook Kim. Resources: Ki Ju Cho, Sang-Wook Kim. Validation: Sang-Wook Kim. Visualization: Ki Ju Cho. Writingoriginal draft: Ki Ju Cho, Sang-Wook Kim. Writing - review \& editing: Sang-Wook Kim.

\section{ORCID}

Sang-Wook Kim https://orcid.org/0000-0002-1681-0556

\section{REFERENCES}

1) Faber CE, Grymer L. Available techniques for objective assessment of upper airway narrowing in snoring and sleep apnea. Sleep Breath 2003;7(2):77-86.
2) Guilleminault C, Hill MW, Simmons FB, Dement WC. Obstructive sleep apnea: Electromyographic and fiberoptic studies. Exp Neurol 1978;62(1):48-67.

3) Goding GS Jr, Eisele DW, Testerman R, Smith PL, Roertgen K, Schwartz AR. Relief of upper airway obstruction with hypoglossal nerve stimulation in the canine. Laryngoscope 1998;108(2):162-9.

4) Mwenge GB, Rombaux P, Dury M, Lengelé B, Rodenstein D. Targeted hypoglossal neurostimulation for obstructive sleep apnoea: A 1-year pilot study. Eur Respir J 2013;41(2):360-7.

5) Strollo PJ Jr, Soose RJ, Maurer JT, de Vries N, Cornelius J, Froymovich $\mathrm{O}$, et al. Upper-airway stimulation for obstructive sleep apnea. N Engl J Med 2014;370(2):139-49.

6) Rathi VK, Kondamuri NS, Naunheim MR, Gadkaree SK, Metson RB, Scangas GA. Use and cost of a hypoglossal nerve stimulator device for obstructive sleep apnea between 2015 and 2018. JAMA Otolaryngol Head Neck Surg 2019;145(10):975-7.

7) Schwab RJ, Gefter WB, Hoffman EA, Gupta KB, Pack AI. Dynamic upper airway imaging during awake respiration in normal subjects and patients with sleep disordered breathing. Am Rev Respir Dis 1993;148(5):1385-400.

8) Morrell MJ, Badr MS. Effects of NREM sleep on dynamic withinbreath changes in upper airway patency in humans. J Appl Physiol (1985) 1998;84(1):190-9.

9) Kryger MH, Roth T, Dement WC. Principles and practice of sleep medicine. 5th ed. Philadelphia, PA: Saunders/Elsevier;2011.

10) Isono $S$, Remmers JE, Tanaka A, Sho Y, Sato J, Nishino T. Anatomy of pharynx in patients with obstructive sleep apnea and in normal subjects. J Appl Physiol (1985) 1997;82(4):1319-26.

11) Badr MS, Toiber F, Skatrud JB, Dempsey J. Pharyngeal narrowing/ occlusion during central sleep apnea. J Appl Physiol (1985) 1995; 78(5):1806-15.

12) Chi L, Comyn FL, Mitra N, Reilly MP, Wan F, Maislin G, et al. Identification of craniofacial risk factors for obstructive sleep apnoea using three-dimensional MRI. Eur Respir J 2011;38(2):348-58.

13) Okubo M, Suzuki M, Horiuchi A, Okabe S, Ikeda K, Higano S, et al. Morphologic analyses of mandible and upper airway soft tissue by MRI of patients with obstructive sleep apnea hypopnea syndrome. Sleep 2006;29(7):909-15.

14) Malhotra A, Huang Y, Fogel RB, Pillar G, Edwards JK, Kikinis R, et al. The male predisposition to pharyngeal collapse: Importance of airway length. Am J Respir Crit Care Med 2002;166(10):138895.

15) Isono $S$, Tanaka A, Tagaito $Y$, Ishikawa $T$, Nishino $T$. Influences of head positions and bite opening on collapsibility of the passive pharynx. J Appl Physiol (1985) 2004;97(1):339-46.

16) Van de Graaff WB. Thoracic influence on upper airway patency. $J$ Appl Physiol (1985) 1988;65(5):2124-31.

17) Genta PR, Edwards BA, Sands SA, Owens RL, Butler JP, Loring $\mathrm{SH}$, et al. Tube law of the pharyngeal airway in sleeping patients with obstructive sleep apnea. Sleep 2016;39(2):337-43.

18) Rowley JA, Sanders CS, Zahn BR, Badr MS. Effect of REM sleep on retroglossal cross-sectional area and compliance in normal subjects. J Appl Physiol (1985) 2001;91(1):239-48.

19) Rowley JA, Zahn BR, Babcock MA, Badr MS. The effect of rapid eye movement (REM) sleep on upper airway mechanics in normal human subjects. J Physiol 1998;510(Pt 3):963-76.

20) Schwartz AR, O'Donnell CP, Baron J, Schubert N, Alam D, Samadi $\mathrm{SD}$, et al. The hypotonic upper airway in obstructive sleep apnea: Role of structures and neuromuscular activity. Am J Respir Crit Care Med 1998;157(4 Pt 1):1051-7.

21) Suratt PM, McTier RF, Wilhoit SC. Upper airway muscle activation is augmented in patients with obstructive sleep apnea compared with that in normal subjects. Am Rev Respir Dis 1988;137(4):88994. 
22) Kryger MH, Roth T, Dement WC. Principles and practice of sleep medicine. 6th ed. Philadelphia, PA: Elsevier;2017. p.xlv, 1, p.1080.

23) Carrera M, Barbé F, Sauleda J, Tomás M, Gómez C, Agustí AG. Patients with obstructive sleep apnea exhibit genioglossus dysfunction that is normalized after treatment with continuous positive airway pressure. Am J Respir Crit Care Med 1999;159(6): 1960-6.

24) Kimoff RJ, Sforza E, Champagne V, Ofiara L, Gendron D. Upper airway sensation in snoring and obstructive sleep apnea. Am J Respir Crit Care Med 2001;164(2):250-5.

25) Kim SW, Park HW, Won SJ, Jeon SY, Jin HR, Lee SJ, et al. Palatal sensory threshold reflects nocturnal hypoxemia and airway occlusion in snorers and obstructive sleep apnea patients. J Clin Sleep Med 2013;9(11):1179-86.

26) Nguyen AT, Jobin V, Payne R, Beauregard J, Naor N, Kimoff RJ. Laryngeal and velopharyngeal sensory impairment in obstructive sleep apnea. Sleep 2005;28(5):585-93.

27) Smith PL, Wise RA, Gold AR, Schwartz AR, Permutt S. Upper airway pressure-flow relationships in obstructive sleep apnea. J Appl Physiol (1985) 1988;64(2):789-95.

28) Aittokallio T, Saaresranta T, Polo-Kantola P, Nevalainen O, Polo O. Analysis of inspiratory flow shapes in patients with partial upperairway obstruction during sleep. Chest 2001;119(1):37-44.

29) Owens RL, Edwards BA, Sands SA, Butler JP, Eckert DJ, White DP, et al. Upper airway collapsibility and patterns of flow limitation at constant end-expiratory lung volume. J Appl Physiol (1985)
2012;113(5):691-9.

30) Eckert DJ, White DP, Jordan AS, Malhotra A, Wellman A. Defining phenotypic causes of obstructive sleep apnea. Identification of novel therapeutic targets. Am J Respir Crit Care Med 2013;188(8): 996-1004.

31) Sands SA, Edwards BA, Terrill PI, Taranto-Montemurro L, Azarbarzin A, Marques M, et al. Phenotyping pharyngeal pathophysiology using polysomnography in patients with obstructive sleep apnea. Am J Respir Crit Care Med 2018;197(9):1187-97.

32) Sands SA, Terrill PI, Edwards BA, Taranto Montemurro L, Azarbarzin A, Marques M, et al. Quantifying the arousal threshold using polysomnography in obstructive sleep apnea. Sleep 2018; 41(1):zsx183.

33) Mann DL, Terrill PI, Azarbarzin A, Mariani S, Franciosini A, Camassa A, et al. Quantifying the magnitude of pharyngeal obstruction during sleep using airflow shape. Eur Respir J 2019; 54(1):1802262.

34) Genta PR, Schorr F, Edwards BA, Wellman A, Lorenzi-Filho G. Discriminating the severity of pharyngeal collapsibility in men using anthropometric and polysomnographic indices. J Clin Sleep Med 2020;16(9):1531-7.

35) Azarbarzin A, Sands SA, Marques M, Genta PR, Taranto-Montemurro L, Messineo L, et al. Palatal prolapse as a signature of expiratory flow limitation and inspiratory palatal collapse in patients with obstructive sleep apnoea. Eur Respir J 2018;51(2):1701419.

\section{정답 및 해설}

1. 답 (5)

해 설 후두유두종은 human papilloma virus(HPV) 6형과 11형이 주를 이룬다. 후두유두종은 점막 질환이다. 양측 및 전연합 부위를 수술하는 경우 격막이나 유착이 발생할 수 있다. 성인형의 경우 자연 소멸되는 경우는 드물다. 참고 문헌: 대한이비인후과학회. 이비인후과학:두경부외과학. 3판. 파주: 군자출판사;2018. p.914, 988.

2. 답 (3)

괴사성 근막염은 당뇨, 전신 증상이 선생되기도 하며, 연부 조직에 gas를 형성한다. 근육과 다른 심부 조직은 일차적으 로 침범하지 않으며, 림프절염과 지역적 림프절증은 드물다. 괴사 조직을 제거하는 중요하며, 항생제 병합요법을 사용한 다. 합병증은 뇌신경증, 혈관미란, 질식, 종격동염이 있을 수 있으며, 치사율은 20 36\%로 높은편이다. 참고 문헌: 대한후두음성언어의학회. 후두음성언어의학. 2판. 서울: 범문에듀케이션;2016. p.424. 